\title{
THE EFFECTIVENESS OF THE USE OF VILLAGE FUNDS IN THE IMPLEMENTATION OF DEVELOPMENT PROGRAMS IN EAST LOMBOK
}

\author{
Zohratul Aeni, Mila Maulana, Teni Susanti, Siti Raehan, Didin Hadi Saputra \\ Universitas Nahdlatul Wathan Mataram, Kota Mataram, Indonesia \\ didinimarc@gmail.com
}

\begin{abstract}
The granting of regional autonomy to the broadest means the granting of authority and power (discretion) to the regions to manage and utilize regional resources optimally. In order to avoid irregularities and deviations, the granting of authority and broad powers must be followed by strong supervision. In this research, the writer or researcher uses qualitative research methods or methods. Namely the research used to examine or see the condition of natural objects or human activities, which are contrary or not in accordance with the experiment, where the researcher is an instrument or key researcher who is the driving force of research, data collection techniques in this study are carried out with a triangulation model (combined), data analysis from this research emphasizes or produces meaning that qualitative research activities are more directed towards generalizing data. In this research, researchers focus on the field of development in infrastructure development programs. Based on the results of research conducted by the author about the effectiveness of the use of village funds in the implementation of programs in the field of development in Suralaga district, East Lombok regency in 2018, it can be measured using a target approach by looking at the outputs of activities, namely the realization of programs and the benefits of the programs classified as very effective.
\end{abstract}

Keywords: Development Goals; East Lombok;, Funds; Transparency.

\section{INTRODUCTION}

Today, the government continues to strive to increase the implementation of National Development so that the pace of regional development and the pace of rural and urban development are more balanced. In this case the local government has full authority in determining policies, planning and implementation to finance. In order to improve the administration of the village government towards achieving village autonomy to create an independent village, there needs to be efforts to organize, manage, explore and mobilize all the potential that exists in the community by providing direct assistance allocated to the village government used to improve community service facilities, institutions and village infrastructure that is needed and prioritized by the community, the utilization and administration of its management carried out and accounted for by the village head.

The granting of regional autonomy to the broadest means the 
EAJ (Economics and Accounting Journal) - Vol. 3, No. 1, Jan 2020 - Aeni, Maulana, Susanti, Raehan \& Saputra

granting of authority and power (discretion) to the regions to manage and utilize regional resources optimally. In order to avoid irregularities and deviations, the granting of authority and broad powers must be followed by strong supervision.

Law No. 6 of 2014 concerning Villages which was then followed up with Government Regulation Number 60 of 2014 concerning Village Funds sourced from the State Revenue and Expenditure Budget, aimed at increasing village independence through programs and activities related to village development and village community empowerment. Based on the provisions in the regulation, effectiveness is one of the things that need to be considered in managing village funds for programs or activities that are in accordance with the objectives of village funds. For what is a policy implemented if it is

\section{LITERATURE REVIEW}

Based on Law Number 6 of 2016 concerning villages, villages are given the authority to regulate and manage their authority in accordance with needs. That means the village funds will be used to fund the overall authority of the village in accordance with the needs and priorities of the village funds. Village funds are funds sourced from the state income and expenditure budget intended for villages that are transferred through the district/city regional income and expenditure budget and are used to finance government administration, development implementation, not effective in helping to overcome various problems in this nation. Specifically, the problems that exist in villages where the village is currently the subject of development and given the authority to manage their own village finances. (Economics and Srinivasan 2019)

Talking about effectiveness and efficiency becomes important in seeing the success or failure of a program of mutually agreed policies. As stated by. In this issue effectiveness and efficiency cannot be linked because the issue of village funds is not about minimizing costs but about how the program from village funds can be maximally provided to village communities. Effectiveness can also be a measure of a truly useful policy in overcoming existing problems. Especially in Indonesia, one of the problems being faced is the low welfare of rural communities.

community development, and community empowerment. The government allocates village funds nationally in the national budget every year from government spending by streamlining villagebased programs equally and equitably.

The Ministerial Regulation also stipulates that the Village Fund is prioritized to finance the implementation of local scale village programs and activities in the field of Village Development and Village Community Empowerment. Priority in the use of Village Funds is based on the principles of Justice, by prioritizing the rights or interests of 
EAJ (Economics and Accounting Journal) - Vol. 3, No. 1, Jan 2020 - Aeni, Maulana, Susanti, Raehan \& Saputra

all villagers without discrimination; Priority Needs, by prioritizing the more pressing interests of the Village, are more needed and are directly related to the interests of the majority of the Village community; and Village Typology, taking into account the circumstances and reality of the village's unique geographical, sociological, anthropological, economic and ecological characteristics, as well as changes or developments in the village's progress.

In order to realize an orderly, transparent, accountable and quality management of village funds, the Government and regencies / cities are given the authority to be able to impose sanctions in the form of delays in the distribution of village funds in the case of reports on the use of village funds that are late / not delivered. In addition, the government and regency / city may also impose sanctions in the form of a reduction in village funds if the use of these funds is not in accordance with the priority of the use of village funds, general guidelines, technical guidelines for activities or depositing money in the form of deposits for more than 2 (two) months. The budget allocation for village funds is set at $10 \%$ (ten percent).

Development is a normative concept that implies the choice of objectives to achieve what is called the realization of human potential. Development is not the same as modernization if we understand clearly the true meaning of the nature of development itself. The essence of national development is humans themselves who are the focal point of all development efforts and what will be built are their abilities and strengths as implementers and what will be built are their abilities and powers as implementers and drivers of development. Basically, village development is carried out by the community together with the government, especially in providing guidance, direction, guidance assistance, and supervision so that the community's ability to improve their standard of living and welfare can be improved (Taçoğlu 2019)

Village development is carried out in the framework of a proper draw between the government and the community. The government's obligation is to provide infrastructure, the rest is based on the ability of the community itself. The village development process is a mechanism of community desires that is integrated with the community (Hitka et al. 2019). Therefore, the implementation needs to be coordinated by the central and regional government as well as the village as a place for the implementation of development so that all of the program activities are mutually supportive and carried out in accordance with the plan so that they can be effective and effective. The problem in rural development is the low assets held by rural communities coupled with the still low access of rural communities to economic resources such as land/land, capital, production inputs, skills and technology, information, and cooperation networks. On the other hand, the low level of infrastructure services and rural facilities and the low quality of human resources in rural areas, mostly low-skilled (low skilled), 
EAJ (Economics and Accounting Journal) - Vol. 3, No. 1, Jan 2020 - Aeni, Maulana, Susanti, Raehan \& Saputra

weak institutional and communitybased organizations, weak crosssectoral coordination in rural area development. In addition, can be used for inter-village development or commonly called rural area development. Rural area development is a combination of inter-village development carried out in an effort to accelerate and improve the quality of services, development, and empowerment of rural communities through a participatory development approach, initiatives to carry out rural area development can be carried out both on up with the proposal of the village head to the regents/mayors and can also topdown as governor or regent/mayor program (Republic 2019).

In carrying out development activities, the community and village government can obtain gradual assistance. Technically, the assistance is carried out by district / city work units and can be assisted by professional advisors, village community empowerment cadres, or third parties.

Physical development is a real manifestation of the development of non-physical aspects that include socio-cultural, socio-economic and so on. The physical development aspect is a real manifestation of the demands that are caused by the growth and development of social and cultural activities of the people ". In other words, the change is identical with the existence or form of development such as the existence of buildings, housing facilities, places of worship, road building facilities, educational facilities, and other public facilities.
The development carried out by the government is generally infrastructure or infrastructure, that is, physical buildings or institutions that have other activities in the economic, socio-cultural, political and security and security fields. Natural resources in each village. Where a village that has a wealth of natural resources is much more than other villages, so to develop or in the process of village development will be far better than villages that have little natural resources, or none at all. (Hitka et al 2019).

The effectiveness of the use of village funds in implementing infrastructure development programs can be measured using the theory of effectiveness measurement (Economics et al. 2019). In this study, the authors used a targeted approach (goal approach). Where in this approach the researchers looked at the extent to which the effectiveness of program implementation by paying attention to the objectives of the program itself. Effectiveness theory is important in organizational theory because effectiveness can provide a picture of the success of the organization in achieving goals that include various factors inside and outside the organization. Effectiveness can be measured by comparing the plans that have been determined with the results achieved. If the objectives of the organization can be said to be effective, but if the results or objectives of the organization are not achieved in accordance with the plan, then it can be said to be ineffective. (Khattak and Jiang 2019) 
EAJ (Economics and Accounting Journal) - Vol. 3, No. 1, Jan 2020 - Aeni, Maulana, Susanti, Raehan \& Saputra

\begin{abstract}
Then see the program implemented by the village government whether the village development goals can be achieved in accordance with the provisions set as a basis for seeing the level of effectiveness of the program. Based on the Regulation of the Minister of Villages, Development of Disadvantaged Regions, and Transmigration No. 21 of 2015 concerning the Determination of Priorities for the Use of Village Funds in 2018 that the Field of Village Development to improve the welfare of rural communities and the quality of human life and poverty reduction.
\end{abstract}

Based on the theory of effectiveness (Khattak and Jiang 2019), the effectiveness of a program can be measured using the target approach. In the target approach, there are several things that need to be considered, namely: the existence of various types of output, the existence of subjectivity in assessment and contextual influence. In this case, the researcher focused on the multiple outputs of village infrastructure development activities and their benefits to the village community. The researcher only examined the products/services produced from the village development program in Dasan Borok village. Based on the Minister of Village Regulation, Development of Underdeveloped Regions and Transmigration No. 21 of 2015 concerning setting priorities for the use of village funds in 2016 in the field of village development aimed at improving the welfare of rural communities and the quality of human life and poverty reduction.
That goal is what the government wants to achieve through a program from the village fund. The amount of funds given to the village government is not half-hearted due to the achievement of these objectives. In this study, the researchers pay attention to outputs (product/service results) and the benefits of infrastructure development programs have been realized by the village government.

\section{RESEARCH METHOD}

In conducting or conducting research this time, the writer and the other team use qualitative research methods or methods. i.e. the method or method used to examine, view and or check the validity of data or the condition of natural objects or human elements, which is contrary to experiment or experiment, in which case the researcher or key instrument in the qualitative method is a key factor or thing main, in using this method, data collection techniques in the field are carried out by triangulation (combined) data, namely analyzing descriptive data from field reviews and qualitative research results emphasizing the meaning rather than generalizing data. In this study, the researchers focused on the field of development in infrastructure development programs.

Village development is a process of change and a more advanced way of life and is also a method for rural communities to be able to build themselves according to their abilities or skills using their resources. Village development is 
EAJ (Economics and Accounting Journal) - Vol. 3, No. 1, Jan 2020 - Aeni, Maulana, Susanti, Raehan \& Saputra

considered quite interesting to study considering the objectives of the field of village development stated in article 78 paragraph (1), namely to improve the welfare of rural communities, improve the quality of human life and poverty alleviation through meeting basic needs, building village facilities and infrastructure, developing local potential and sustainable use of natural resources and the environment.

Furthermore, in the implementation of village development, it is important to prioritize the mainstreaming of peace and social justice as stated in article 78 paragraph (3). In the sense that the village government and the community must be able to synergize well in order to achieve the principles of village development.

The East Lombok Regional Government has completed seven programs in the field of village community empowerment. The field of community empowerment aims to increase the capacity of citizens or village communities in developing entrepreneurship, increasing income and expanding the economic scale of individual citizens or community groups and villages. The program has covered all the objectives of the community empowerment program. Most communities carry out capacity training activities to increase the knowledge of citizens in accordance with their fields. In this study, the authors only focus on village infrastructure development programs. Following is a description of the results of research on the implementation of infrastructure development programs and their benefits to the community.

\section{RESULTS AND DISCUSSION}

In this case, the aim of improving the welfare of the village community has been carried out infrastructure development program. From the results of these interviews, the villagers have benefited from the village infrastructure development programs. Although not all sectors are sufficient to have and have positive or beneficial effects or effects on improving and growing the welfare and comfort of rural communities.

In general, programs that have been realized have more impact physical facilities and infrastructure for livelihoods including food security and have a less role in poverty reduction. Through activities that involve the role of the community as construction workers have more or less helped the economy of its citizens. Through infrastructure development programs as a form of improvement physical facilities and infrastructure to boost or increase the amount of community livelihoods including resilience in achieving food security and settlement. this has been seen in the economic situation of the people.

Of all the programs that have been realized, there are no visible special programs aimed at improving the quality of human life. However, through infrastructure development such as road improvement, it certainly affects all levels of society. Good road conditions will certainly 
EAJ (Economics and Accounting Journal) - Vol. 3, No. 1, Jan 2020 - Aeni, Maulana, Susanti, Raehan \& Saputra

make it easier for residents' children to get to their schools on time.

Furthermore, good road conditions and the development in the agricultural sector are none other than a source of income for villagers. the existence of farm roads can make it easier for farmers to transport their crops, this has an impact on increasing the income of citizens. Then the drainage in settlements prone to waterlogging now makes the settlement-free from flooding due to rain or wastewater and is now much cleaner. Then by working on the program in a self-managed manner, it provides an opportunity for residents to actively participate and participate to increase their income. This is very useful for

\subsection{Discussion}

The East Lombok Regional Government has completed seven programs in the field of village community empowerment. The field of community empowerment aims to increase the capacity of residents or village communities in developing entrepreneurship, increasing income and expanding the economies of scale of individual citizens or community groups and villages. The program has covered all the objectives of the community empowerment program. Most communities carry out capacity training activities to increase the knowledge of citizens in accordance with their fields. In this study the authors only focus on village infrastructure development programs. Following is a description of the results of research on the implementation of infrastructure improving the welfare of rural communities which also has an impact on tackling existing poverty.

Through infrastructure development, improvement of public facilities and infrastructure can have an impact on improving the for the welfare and comfort of the community, as well as improving the quality of the human life process and even reducing poverty. The use of targeted village funds will facilitate the achievement of objectives. Therefore, the village government as the manager of village funds together with the community as the target and supervisor of activities must be able to work well together to achieve the objectives of village development.

development programs and their benefits to the community.

Drainage is the disposal of water masses naturally or artificially from the surface or subsurface of a place. Surface drainage channels are usually in the form of a trench that is built firmly so that it can function properly. Some of the benefits of drainage are to drain rainwater infiltration into the community's environment toward a river body, the environment can be neater, not muddy and flooded, and to improve village spatial planning. However, the most often felt is to prevent flooding because water channels can be launched with this drainage.

It can be seen that with the drainage built around residential areas, it is very helpful to solve the wastewater problem. Evidenced by the not flooding of residential areas when the rainy season arrives. The 
EAJ (Economics and Accounting Journal) - Vol. 3, No. 1, Jan 2020 - Aeni, Maulana, Susanti, Raehan \& Saputra

waterways are smooth and the residents are neater and cleaner because they are no longer muddy and muddy as before. Then another benefit is providing the opportunity for residents to actively participate in the construction of this drainage. residents participate in doing this activity, so they feel involved in every government activity. This gives a positive value for the villagers.

In general, programs that have been realized have more impact on improving the welfare of rural communities and have a less role in poverty reduction. Through activities that involve the role of the community as construction workers have more or less helped the economy of its citizens. Through infrastructure development programs as a form of improvement of physical facilities and infrastructure for livelihoods including food security and settlement. this has been seen in the economic situation of the people.

Of all the programs that have been realized, there are no visible special programs aimed at improving the quality of human life. However, through infrastructure development such as road improvement, it certainly affects all levels of society. Good road conditions will certainly make it easier for residents' children to get to their schools on time.

Furthermore, good road conditions and the development of talud in the agricultural sector are none other than a source of income for villagers. the existence of farm roads can make it easier for farmers to transport their crops, this has an impact on increasing the income of citizens. Then the drainage in settlements prone to waterlogging now makes the settlement-free from flooding due to rain or wastewater and is now much cleaner. Then by working on the program in a self-managed manner, it provides an opportunity for residents to actively participate and participate to increase their income. This is very useful for improving the welfare of rural communities which also has an impact on tackling existing poverty.

\section{CONCLUSION}

Based on the results of research conducted by the author on the effectiveness of the use of village funds in the implementation of programs in the field of village development in East Lombok regency in 2018 can be measured using the target approach (goal approach) with see the output of activities namely the realization of the program and the benefits of the program is classified as very effective.

\section{REFERENCES}

Çelikkol, Mutlu. (2019). Culture' $S$ Impact On Entrepreneurship \& Interaction Effect Of Economic

Development Level: An 81 Country Study. 20(4): 777-97.

Economics, Business, Miroslava Knapkov, Martin Kiaba, And 
EAJ (Economics and Accounting Journal) - Vol. 3, No. 1, Jan 2020 - Aeni, Maulana, Susanti, Raehan \& Saputra

Samuel Hudec. (2019). Impact Of Macroeconomic Indicators. 20(4): 734-53.

Economics, Business, And Suresh Srinivasan. (2019). Tacit Knowledge And Firm Performance Relationship . The Role Of Product Innovation And The Firm Level Capabilities. 20(2): 330-50.

Hitka, Miloš, Zoltán Rózsa, Marek Potkány, And Lenka Ližbetinová. (2019). Factors Forming Employee Motivation Influenced By Regional And Age-Related Differences. 20(4): 674-93.

Khattak, Shoukat Iqbal, And Qingquan Jiang. (2019). Corporate Social Responsibility
( Csr ) And Leadership: Validation of A Multi-Factor Framework In The United Kingdom ( Uk ). 20(4): 754-76.

Kirikkaleli, Dervis. (2019). Innovation Capacity, Business Sophistication And Macroeconomic Stability: Empirical Evidence From OECD Countries. 20(2): 35167.

Republic, Czech. (2019). Different Influence Of Cooperation And Public Funding On Innovation Activities. 20(2): 384-97.

Taçoğlu, Caner. (2019). Analysis Of Variables Affecting Competitiveness. 20(4): 648-73. 